\title{
JNPH
}

Volume 4 No. 2 (Desember 2016)

(C) The Author(s) 2016

\section{HUBUNGAN PENGETAHUAN SIKAP DAN PRAKTEK PERSONAL HYGIENE DENGAN KEJADIAN KEPUTIHAN REMAJA PUTRI DI SMA N 4 KOTA BENGKULU}

\section{CORRELATION OF KNOWLEDGE ATTITUDE AND PRACTICE OF PERSONAL HYGIENE WITH YOUNG WOMEN'S EVENTS WHITISH IN SMA N 4 BENGKULU CITY}

\author{
IDA SAMIDAH, RAVIKA RAMLIS \\ STIKES DEHASEN BENGKULU PROGRAM STUDI KEPERAWATAN \\ EMAIL: IDASAMIDAH@YAHOO.CO.ID
}

\begin{abstract}
ABSTRAK
World Health Organization (WHO) juga menyebutkan bahwa angka kejadian keputihan di Eropa hanya $25 \%$ saja sedangkan di Indonesia Lebih dari $70 \%$ wanita mengalami keputihan. Faktor-faktor yang dapat mempengaruhi keputihan antara lain dapat disebabkan oleh kurang baiknya pesonal hygiene, pengetahuan dan sikap yang kurang baik mengenai keputihan. Tujuan penelitian ini untuk mengetahui hubungan pengetahuan, sikap dan praktek personal hygiene dengan kejadian keputihan remaja putri di SMAN 4 Kota Bengkulu. Metode penelitian ini menggunakan desian deskriptif analitik, menggunakan desain cross-sectional. Populasi dalam penelitian ini adalah seluruh siswi SMAN 4 Bengkulu pada yang berjumlah 499 orang dengan jumlah sampel 77 responden diambil dengan teknik random sampling. Pengumpulan data dalam penelitian ini menggunakan data primer dan skunder, dianalisis dengan univariat menggunakan tabel distribusi frekuensi dan bivariat menggunakan uji chi scuare. Hasil penelitian ini menunjukkan bahwa Hampir dari sebagian responden (46,8\%) mempunyai pengetahuan yang kurang tentang keputihan, sebagian dari responden $(50,6 \%)$, mempunyai sikap yang unfavorabel terhadap keputihan, sebagian besar responden $(57,1 \%)$, kurang baik dalam melakukan personal hygiene, sebagian besar responden $(66,2 \%)$, mengalami keputihan. Ada hubungan antara pengetahuan, sikap dan personal hygiene dengan Kejadian Keputihan Remaja Putri di SMAN 4 Kota Bengkulu. Kepada pihak SMAN 4 Kota Bengkulu diharapkan dapat meningkatkan pengetahuan kesehatan remaja tentang kesehatan reproduksi dengan mengadakan pendidikan kesehatan reproduksi yang dimasukan kedalam kurikulum pendidikan.
\end{abstract}

Kata Kunci: Pengetahuan, Sikap, Personal Hygiene, Keputihan

\begin{abstract}
World Health Organization (WHO) also mentions that the incidence of vaginal discharge in Europe only $25 \%$, while in Indonesia More than $70 \%$ of women experience vaginal discharge. Factors that may affect the whiteness among others, can be caused by lack of good pesonal hygiene, knowledge and attitudes unfavorable about whiteness. The purpose of this study to determine the relationship of knowledge, attitude and practice personal hygiene to the events whitish SMAN 4 teenage girls in the city of Bengkulu. This research method using descriptive analytic desian, using cross-sectional design. The population in this study are all SMAN 4
\end{abstract}


Bengkulu on numbering 499 people with a total sample of 77 respondents taken by random sampling technique. Collecting data in this study using primary and secondary data, were analyzed using univariate and bivariate frequency distribution table using chi scuare. The results of this study show that almost from the majority of respondents $(46.8 \%)$ have less knowledge about the whiteness, the majority of respondents $(50.6 \%)$, have unfavorabel attitude toward whiteness, the majority of respondents $(57.1 \%)$, less good at doing personal hygiene, most respondents (66.2\%), experience vaginal discharge, There is a relationship between knowledge, attitude and personal hygiene with Genesis whitish Young Women in SMAN 4 Kota Bengkulu. To the SMAN 4 Kota Bengkulu expected to increase the health knowledge of adolescents on reproductive health by conducting reproductive health education is incorporated into the educational curriculum.

\section{Keywords: Knowledge, Attitudes, Personal Hygiene, Whitish}

\section{PENDAHULUAN}

Keputihan dibagi menjadi keputihan fisiologis dan patologis. Penyebab keputihan yang patologis bermacam-macam, dapat disebabkan oleh adanya infeksi jamur (Candida albicans), parasit (Trichomonas vaginalis), bakteri dan virus, adanya benda asing dalam liang senggama, gangguan hormonal akibat haid, kelainan didapat atau bawaan dari alat kelamin wanita, adanya kanker atau keganasan pada alat kelamin. Selain itu kebiasaan seperti membersihkan vagina dengan menggunakan obat antiseptik ataupun sering melakukan hubungan seksual dapat memicu ketidakseimbangan jamur dan kuman-kuman normal dalam vagina yang menyebabkan keputihan (Muhammad, 2011).

Hasil penelitian terdahulu yang dilakukan Ayuningtyas tahun 2011 di SMA Negeri 4 Semarang menunjukkan bahwa sebagian besar siswi memiliki pengetahuan menjaga kebersihan genitalia eksterna yang buruk $(82,8 \%)$. Hasil penelitian ini juga menunjukkan bahwa ada hubungan antara pengetahuan menjaga kebersihan genitalia eksterna dengan kejadian keputihan pada siswi SMA Negeri 4 Semarang $(p=0,027)$. Hasil penelitian Sari tahun 2012 Di SMA Negeri I Seunuddon Kabupaten Aceh Utara menunjukkan bahwa ada hubungan prilaku personal hygiene remaja putri dengan kejadian keputihan $(\mathrm{p}=0,00)$.

Survey awal di SMAN 4 Kota Bengkulu didapatkan data bahwa jumlah siswi sebanyak 499 orang, dimana semua remaja putri tersebut mempunyai resiko terhadap terjadinya keputihan yang bisa disebabkan oleh hormon tubuh maupun tanda infeksi. Jika masalah keputihan ini tidak segera dideteksi secara dini oleh remaja dapat mempengaruhi kesehatan remaja dimasa yang akan datang, maka dari itu pengetahuan tentang keputihan, sikap yang baik dalam baik dalam mencegah keputihan dan upaya melakukan dalam menjaga kebersihan diri sangat penting dilakukan oleh remaja dalam meminimalkan terjadinya keputihan.

Wawancara peneliti saat melakukan prapenelitian di SMAN 4 Kota Bengkulu diketahui bahwa dari 10 siswi pernah mengalami keputihan, dari 10 siswi diketaui 3 orang melakukan kebersihan alat reproduksinya dengan baik sedangkan 7 orang lainya tidak melakukan kebersihan alat reproduksinya dengan baik seperti saat mencuci alat reproduksinya setelah buang air kecil biasanya dilakukan dari arah anus ke vagina, ada juga yang mengatakan tidak mengelap sampai kering setelah mencucinya bahkan ada yang mengatakan saat menstruasi mereka jarang mengganti pembalut kecuali sudah merasa tidak nyaman hal ini sangat berbahaya karena dari perilaku yang tidak baik dari remaja sisiwi dalam menjaga kebersihan organ reproduksinya dapat menyebabkan keputihan. Dari hasil wawancara peneliti ini juga diketahui bahwa siswi tersebut mengatakan kurang mengerti tentang perawatan kebersihan organ reproduksi mereka terutama saat menstruasi, berapa kali harus mengganti pembalut dan 
bagaimana cara mencuci organ reproduksi yang baik dan benar.

Berdasarkan dari latar belakang yang dikemukakan di atas maka peneliti tertarik untuk mengadakan penelitian guna mengetahui " hubungan pengetahuan, sikap dan praktek personal hygiene dengan kejadian keputihan remaja putri di SMAN 4 Kota Bengkulu”.

\section{METODOLOGI PENELITIAN}

Jenis penelitian ini adalah penelitian menggunakan rancangan penelitian cross sectional yaitu mengukur variabel eksogen dan endogen di suatu saat secara bersamaan dan data yang diperoleh menggambarkan kondisi yang terjadi saat penelitian dilaksanakan.

Populasi dari penelitian ini adalah seluruh anak usia 1-6 tahun di Rumah Sakit M. Yunus Bengkulu dari bulan Januari sampai Juni yang berjumlah 66 orang. Penelitian ini dilakukan dari bulan Oktober sampai bulan November 2015.

Data yang terkumpul berdasarkan pedoman penskoran menurut variable penelitian kemudian data dijumlahkan berdasarkan kuesioner pada setiap alternative jawaban kemudian melalui beberapa tahap pengolahan data: Mengedit (Editing), pengkodean (Coding), entry data, pembersihan data (Cleaning), analisis Data yang terdiri dari analisa univariat dan analisa bivariat.

\section{HASIL PENELITIAN}

Data yang diperoleh kemudian diolah menggunakan program komputer dengan spss 16, dari hasil pengolahan data maka dilakukan analisis Univariat melihat hubungan antara variabel independen dengan variabel dependen menggunakan chi-square dengan tingkat kepercayaan $95 \%$ dan $\alpha 5 \%$.

Adapun hasil analisisnya sebagai berikut:

Tabel 1 Hasil pengujian validitas variabel Sikap

\begin{tabular}{cccc}
\hline Nomor Butir & $\mathrm{R}_{\text {hit }}$ & $\begin{array}{c}\mathrm{R}_{\mathrm{tab}} \\
(5 \%)\end{array}$ & Ket. \\
\hline Penggunaan Pembalut & & & \\
\hline 1 & 0,401 & 0,361 & Valid \\
\hline 2 & 0,764 & 0,361 & Valid \\
\hline 3 & 0,803 & 0,361 & Valid \\
\hline 4 & 0,672 & 0,361 & Valid \\
\hline 5 & 0,919 & 0,361 & Valid \\
\hline $\begin{array}{c}\text { Mencuci Genetalia } \\
\text { pada saat Menstruasi }\end{array}$ & & & \\
\hline 1 & 0,818 & 0,361 & Valid \\
\hline 2 & 0,591 & 0,361 & Valid \\
\hline 3 & 0,802 & 0,361 & Valid \\
\hline 4 & 0,526 & 0,361 & Valid \\
\hline 5 & 0,548 & 0,361 & Valid \\
\hline Penggunaan Pakaian & & & \\
Dalam & & & \\
\hline 1 & 0,654 & 0,361 & Valid \\
\hline 2 & 0,561 & 0,361 & Valid \\
\hline 3 & 0,576 & 0,361 & Valid \\
\hline 4 & 0,519 & 0,361 & Valid \\
\hline 5 & - & 0,361 & Tidak \\
\hline & 0,022 & & Valid \\
\hline & & &
\end{tabular}

Berdasarkan tabel 1 menunjukkan bahwa sikap remaja putri terhadap perilaku remaja putri di SMPN 2 Kota Bengkulu menunjukkan terdapat pengaruh langsung sebesar $42,6 \%$.

Tabel 2 Hasil pengujian validitas variabel peran teman sebaya

\begin{tabular}{cccc}
\hline Nomor Butir & $\mathrm{R}_{\text {hit }}$ & $\mathrm{R}_{\operatorname{tab}}(5 \%)$ & Ket. \\
\hline Informasi & & & \\
\hline 1 & 0.672 & 0,361 & Valid \\
\hline 2 & 0,803 & 0,361 & Valid \\
\hline 3 & 0,764 & 0,361 & Valid \\
\hline 4 & 0,919 & 0,361 & Valid \\
\hline 5 & 0,401 & 0,361 & Valid \\
\hline Pendamping & & & \\
\hline 1 & 0,561 & 0,361 & Valid \\
\hline 2 & 0,642 & 0,361 & Valid \\
\hline 3 & 0,576 & 0,361 & Valid \\
\hline 4 & 0,555 & 0,361 & Valid \\
\hline 5 & 0,441 & 0,361 & Valid \\
\hline Inspirasi & & & \\
\hline 1 & 0,563 & 0,361 & Valid \\
\hline 2 & 0,559 & 0,361 & Valid \\
\hline 3 & 0,570 & 0,361 & Valid \\
\hline 4 & 0,652 & 0,361 & Valid \\
\hline 5 & 0,294 & 0,361 & Tidak \\
\hline & & & Valid \\
\hline
\end{tabular}

Berdasarkan tabel 2 menunjukkan bahwa 
peran teman sebaya terhadap perilaku remaja putri di SMPN 2 Kota Bengkulu menunjukkan terdapat pengaruh langsung sebesar 5,7\%, sedangkan untuk pengaruh tidak langsung peran teman sebaya terhadap perilaku remaja putri melalui sikap sebesar $6,84 \%$.

Tabel 3 Hasil pengujian validitas variabel peran Ibu

\begin{tabular}{cccc}
\hline Nomor Butir & $\mathrm{R}_{\text {hit }}$ & $\mathrm{R}_{\mathrm{tab}}(5 \%)$ & Ket. \\
\hline Pendidik & & & \\
\hline 1 & 0.764 & 0,361 & Valid \\
\hline 2 & 0,803 & 0,361 & Valid \\
\hline 3 & 0,919 & 0,361 & Valid \\
\hline 4 & 0,672 & 0,361 & Valid \\
\hline 5 & 0,401 & 0,361 & Valid \\
\hline Panutan & & & \\
\hline 1 & 0,602 & 0,361 & Valid \\
\hline 2 & 0,406 & 0,361 & Valid \\
\hline 3 & 0,537 & 0,361 & Valid \\
\hline 4 & 0,590 & 0,361 & Valid \\
\hline 5 & 0,344 & 0,361 & Tidak \\
\hline \multicolumn{5}{c}{} & & Valid \\
\hline 1 & 0,738 & 0,361 & Valid \\
\hline 2 & 0,569 & 0,361 & Valid \\
\hline 3 & 0,692 & 0,361 & Valid \\
\hline 4 & 0,593 & 0,361 & Valid \\
\hline 5 & 0,443 & 0,361 & Valid \\
\hline
\end{tabular}

Berdasarkan tabel 3 menunjukkan bahwa peran ibu terhadap perilaku remaja putri di SMPN 2 Kota Bengkulu menunjukkan terdapat pengaruh langsung sebesar 19,9\%, sedangkan untuk pengaruh tidak langsung peran ibu terhadap perilaku remaja putri melalui sikap remaja putri sebesar 15,58\% Peran ibu berpengaruh positif terhadap perilaku remaja putri di SMPN 2 Kota Bengkulu sebesar 0,277 dan nilai T-Statistik signifikan sebesar 4.

Hasil uji Chi-Square diperoleh Pearson Chi-Square diperoleh nilai $\chi^{2}=4.185$ dengan nilai $\mathrm{p}=0,000<0,05$, jadi signifikan, sehingga Ho ditolak dan Ha diterima, artinya ada hubungan yang signifikan antara pengetahuan dengan perilaku.

\section{PEMBAHASAN}

Hasil penelitian ini memunjukkan bahwa ada pengaruh langsung peran teman sebaya terhadap perilaku remaja putri dalam menjaga kebersihan genetalia pada saat menstruasi sebesar 5,7\%. Ada pengaruh langsung peran teman sebaya terhadap sikap remaja putri sebesar $16 \%$. Ada pengaruh langsung peran ibu terhadap perilaku remaja putri dalam menjaga kebersihan genetalia pada saat menstruasi sebesar 19,7\%. Ada pengaruh langsung peran ibu terhadap sikap remaja putri sebesar $36,6 \%$. Ada pengaruh langsung sikap remaja putri terhadap perilaku remaja putri dalam menjaga kebersihan genetalia pada saat menstruasi sebesar $42,6 \%$.

Hasil penelitian ini dapat menjelaskan dan memperkuat hasil penelitian mengenai pengaruh sikap terhadap perilaku, diantaranya penelitian yang dilakukan oleh Hani Handayani (2011) dengan judul Hubungan pengetahuan, sikap dan perilaku remaja putri tentang kebersihan organ genetalia eksternal di MTs Pembangunan Tahun 2011, hasil hubungan sikap dengan prilaku (pvalue $=0,017$ ). Penelitian Iis Farida (2012) judul penelitian pengaruh pengetahuan dan sikap remaja serta pengawasan ibu terhadap perilaku seksual dalam berpacaran di SMAN 1 Cilamaya Karawang Tahun 2012, sikap berpengaruh positif dan signifikan dengan perilaku seksual berpacaran sebesar $0,424 \mathrm{~T}$ Statistik sikap terhadap perilaku sebesar 6.023, penelitian Hasanah (2010) pengaruh pengetahuan dan sikap dengan perilaku perawatan organ genetalia eksterna pada siswa SMAN Futtuhiyyah Mranggen Demak. Penelitian Mirna ayu (2013) dengan judul Hubungan pengetahuan dan sikap dengan perilaku kesehatan reproduksi pada remaja putri di SMA 5 Banda Aceh, hasil penelitiannya ada hubungan antara sikap dengan perilaku remaja dengan nilai $(p=$ 0.007 ).

Hasil penelitian ini dapat menjelaskan dan memperkuat hasil penelitian mengenai pengaruh peran ibu terhadap perilaku, diantaranya penelitian yang dilakukan oleh 
Chusnul (2011) dengan judul penelitian hubungan antara sumber informasi dan pengetahuan tentang menstruasi dengan perilaku personal hygiene selama menstruasi di SMPN 1 kebonarum kabupaten Klaten dengan hasil (pvalue $=0.000$ ). Penelitian Rini Kundaryanti (2011) dengan judul penelitian faktor-faktor yang berhubungan dengan perilaku seksual remaja di SMK Yaperjasa Jakarta tahun 2011, dengan hasil ada hubungan antara peran ibu dengan perilaku (pvalue 0.00) .

Hasnadi (2002) menyatakan peranan ibu menggambarkan seperangkat perilaku antar pribadi, sifat dan kegiatan yang berhubungan dengan pribadi dalam posisi dan situasi tertentu. Peranan pribadi dalam ibu didasari oleh harapan dan pola perilaku dari ibu, kelompok dan masyarakat. Jadi ibu merupakan orang yang pertama kali yang mengajarkan bagaimana cara berprilaku menjaga kebersihan genetalia pada saat menstruasi pada anak remajanya.

\section{SARAN}

Hasil penelitian ini dapat dijadikan acuan bahwa dalam mengingat sikap yang berujung kepada perilaku remaja putri dalam menjaga kebersihan genetalia pada saat menstruasi, hal penting yang perlu ditindak lanjuti yaitu sikap remaja putri yang harus diperbaiki yaitu dengan cara di adakannya seminar-seminar, pendidikan kesehatan dan tersedianya media informasi tentang cara menjaga kebersihan genetalia pada saat menstruasi dan akibat jika tidak menjaga genetalia pada saat menstruasi, upaya ini agar siswa tahu, dengan banyaknya pengetahuan remaja putri tentatang cara menjaga kebersihan genetalia pada saat menstruasi di harapkan sikap remaja akan baik, jika sikap remaja sudah baik diharapkan perilakunya juga baik dalam menjaga kebersihan genetalia pada saat menstruasi.

\section{DAFTAR PUSTAKA}

Abdul, Kaharto dkk. 2006. Pencegahan Kelainan pada Masa Kehamilan. digilib.esaunggul.ac.id. Dikases

Februari 2015.

Bare. 2012. Pengaruh Kehamilan Terhadap Kejadian Hipertensi Pada Ibu Hamil Di Rumah Sakit Kesehatan Ibu Dan Anak Jakarta (Tesis) Fakultas Keperawatan Universitas Indonesia

Anderson dan Neurhouser. 2012. Riset dalam Ilmu Kebidanan. Nuha Medika: Yogyakarta.

Ardiansyah, Muhamad. 2012. Medikal Bedah Untuk Mahasiswa. Diva Press: Jakarta.

Asmadi. 2008. Tehnik Prosedural Keperawatan: Konsep dan Applikasi Kebutuhan Dasar Klien. Salemba Medika: Jakarta.

Baradero. 2008. Penyakit Kardiovaskuler dan Penangannya. EGC: Jakarta.

BKKBN, et al. 2011. Program KB dan Peningkatan Jumlah Penduduk Indonesia: Jakarta.

Brunner dan Suddarth. 2000. Keperawatan Medikal Bedah Edisi 8 Volume 2. EGC: Jakarta.

Bedah Edisi 8 Volume 2. EGC: Jakarta.

Chapman, Vicky. 2006. Asuhan Kebidanan Persalinan dan Kelahiran. EGC: Jakarta. Cuningham, Jhon. 2006. Ilmu Kebidanan dan Kandungan. Medika Press: Jakarta.

2011. Kebidanan dalam

Kesehatan Masyarakat. Medika Press: Jakarta.

Fredrick, albert dkk.2009. Pengantar Ilmu Kebidanan. Media Press: Jakarta.

Hanifa, Wiknjosastro. 2006. Ilmu Kebidanan. EGC: Jakarta.

Hawari. 2004. Stress dan Ilmu Psikologi. Pustaka Mediak: Jakarta.

Hidayat, Azis Aimul. 2007. Kebutuhan Dasar Manusia. Rineka Cipta: Jakarta.

Idrus, Muhammad. Hubungan Kenaikan Berat Badan saat Hamil Dengan Kejadian Preeklampsia Pada Ibu Hamil Trimester III di Rumah Sakit Chikini Jakarta. (Tesis) Universitas Muhammadiyah Jakarta.

Kruger GO. 2005. Pengantar dan Paradigma Ilmu Kebidanan. EGC: Jakarta. 
Lestari, Puji. 2012. Faktor-Faktor Yang Mempengaruhi Preeklampsia pada Ibu Hamil di RS.Cipto Mangunkusomo (Skripsi) Universitas Indonesia.

Mandy, Akfar. 2010. Kehamilan yang Menyenangkan. http://id.wikipedia.org. Diakses 27 Februari 2015.

Mansjoer dkk. 2007. Memahami Kesehatan Reproduksi Wanita. Jakarta: EGC.

Manuaba, Ida Bagus Gde. 2008. Memahami Kesehatan Reproduksi Wanita. EGC: Jakarta.

Maryuni, Anik. 2010. Asuhan Kegawatdaruratan Dalam Kebidanan. Trans Info Media: Jakarta.

2012. Asuhan Kebidanan. Trans Info Media: Jakarta.

Minarti. 2000. Hubungan Obesitas, Penambahan Berat Badan dan Stress dengan Kejadian Preeklampsia Pada Ibu Hamil di RSUD Prof. Dr. Margono Soekardjo Purwokerto. Universitas Indonesia Jakarta.

Muttaqin, Arif. 2011. Pengantar Asuhan Keperawatan Maternitas. Salemba Medika: Jakarta.

Notoatmodjo, Soekidjo. 2010. Ilmu Perilaku Kesehatan. Rieneka Cipta: Jakarta.

Osungbade. 2011. Perspektif Kesehatan Refroduksi dalam Tatanan Kesehatan Masyarakat. EGC: Jakarta.

Priambojo,Kartono. 2013. Hubungan Paritas dan Stress Terhadap Peningkatan Tekanan Darah pada Ibu Hamil di RS.Abdul Muluk. (Skripsi) FKM UniversitasLampung.

Rachimhadhi, Trijatmo. 2007. Peningkatan Status Kesehatan Demi Pencapaian Pilar MDGs. Pustaka Medika: Jakarta

Rahmawati. 2009. Peningkatan Berat Badan Dalam Kehamilan. EGC: Jakarta.

Rokhita. 2007. Preeklampsia Selama Kehamilan. Rineka Cipta: Jakarta.

Rozhikan. 2007. Manajemen Stress. Nuha Medika: Jakarta.

Sarwono, Prawiharjo. 2010. Panduan Praktis Pelayanan Kesehatan Maternal dan Neonatal. YBPSP: Jakarta. 